\title{
Innovation Networks: A Tool for Food-Culture Preservation and Sustainability in the Era of Globalization
}

\author{
Ibrahim Baghdadi ${ }^{1}$ \\ ${ }^{1}$ Faculty of Hospitality and Tourism Management, Lebanese University, Beirut, Lebanon \\ Correspondence: Ibrahim Baghdadi, Researcher in Economics of Development and Sustainability, Lebanese \\ University, Faculty of Hospitality and Tourism Management, Beirut, P.O. Box 6573/14 Badaro, Lebanon. E-mail: \\ Ibrahim_baghdadi@yahoo.com
}

Received: October 15, 2018

Accepted: December 28, $2018 \quad$ Online Published: January 31, 2019

doi: $10.5539 /$ jsd.v12n1p10

URL: https://doi.org/10.5539/jsd.v12n1p10

\begin{abstract}
The growing exposure to globalization, since 1990s, has initiated some significant alterations to the Lebanese economy, society, and culture. For the last two decades, it has been observed that international cuisines and eccentric menu items have been invading the local market and taking over ethnic and traditional cuisines, what threatens, if this trend continues, the identity of traditional cuisine and, consequently, the sustainability of local food culture.

Departing from the case of Lebanon, this paper studies the impact of globalization on traditional cuisine and highlights the role of networks in sustaining local food culture. The findings of our empirical study revealed the necessity to modernize the traditional cuisine through a coordinated set of heterogeneous and professional actors who collectively take part in the process. The ability of these actors to innovate is found related to the organizational conditions of the networks to which they belong, and to the ability of these networks for innovation, what refers us to the concept of "innovation network" that we are proposing, through this study, as a solution to the dilemma of food - culture preservation and sustainability.
\end{abstract}

Keywords: globalization, social capital, innovation networks, food culture, sustainability.

\section{Introduction}

The Lebanese cuisine is known for its legendary savor and its lavish food varieties, what makes it one of the greatest cuisines of the Middle East, and particularly the Levant. These characteristics result from cultural amalgamation and accumulation of the different civilizations that occupied Lebanon over the years, adding to that, the traditions of local communities who developed their own recipes based on territorial specialties.

Going back into history, the Lebanese cuisine has evolved rapidly and presented a substantial inclination towards modernization since the end of the civil war in 1990 and the apparition of internet which facilitated the openness of the country to globalization. One of the aspects of globalization is the fast spread of international restaurants, especially those from developed countries. According to the MOT (2018), 407 international restaurant concepts that opened between the years 2000 and 2017, compared to 192 traditional Lebanese restaurants that opened during the same period.

Several indicators may explain this phenomena, starting with the readiness of local market for globalization and its openness to perfect competition that gradually outcompeted local restaurants and finally, the competitive advantage of international cuisines (based on advanced technology, economies of scale and economies of scope, research, creative strategic planning, high financial leverage, etc.). These indicators and others may twist the national economy (Belasco, 2002) and threaten the national culture (Bérard \& Marchenay, 2004). On a microeconomic scale, the creativity and innovation of international restaurants have persuaded local ones (especially those specialized in traditional food) to modernize their cuisine, what caused a gradual displacement of the identity of traditional Lebanese cuisine and led us to wonder whether globalization represents a real threat or an opportunity to national economy and culture.

Based on a literature review about social capital, networks and the impacts of globalization on local food culture and sustainable development, in addition to an empirical study about the choice and preferences of local communities in terms of restaurant type and concept, this paper aims to: 1) study the factors that affect the 
choice of the local market and are at the origin of the changing trends, 2) determine the impacts of globalization on local food culture and sociocultural sustainability, 3) define how globalization may contribute to enhance local food culture or, at least, reconstruct local food values and traditions and, 4) propose the "innovation network" as a system of collective action that favors the compromise between sociocultural sustainability and modernization.

Going back to the roots of the problem, one should question about the factors that stand behind the changing trends of local community and whether they are endogenous or exogenous. From this standpoint a survey was conducted on 100 restaurants (theme and ethnic) selected from different regions in Lebanon between May and August 2018, the survey was conducted during different meal periods (breakfast, lunch and dinner) on a randomly selected sample of 2600 diners using a questionnaire, the response rate was $89.23 \%$ ( 2320 respondents) but 1990 responses were left after sorting and cleaning data. The findings of the study revealed that price, portion size, menu choice and service (most of which are usually provided by international cuisines) are the main determining factors of restaurant concept in Lebanon while food quality and taste, food creativity, food variety and annual income are the determining factors of restaurant type.

Generally speaking, the results of the study have brought into sight the factors that explain the general inclination towards modernizing the traditional cuisine. Bearing in mind the negative impacts of this modernization on the identity of traditional cuisine and local food culture, this paper proposes the concept of "innovation networks" as a solution.

\section{Traditional Cuisine and Food Culture}

"Foods are conceptualized as authentic products that symbolize the place and culture of the destination" (Sims, 2009, p. 321).

The association between, on the first hand, traditional cuisine and, on the other hand, culture and identity have long been studied by researchers in social science such as (Richards, 1939) and (Douglas, 1971). According to Lévi Strauss (1968), cooking is important as it transforms natural objects into cultural ones. As for Fischler (1980), food is one of the components of culture, it represents a nation's identity that has been formed through successive generations, it symbolizes the exclusive history, traditions, values and ethnicity. Hippocrates (460-370 BC) once said: "we are what we eat", this is true as our food preferences and choices are influenced by our culture forces (Fallon, Rozin, \& Pliner, 1984). Hence, the food we eat mirrors our morals, our life style, our civilization, our traditional values, our creativity and development. From this standpoint, it is obvious that the food we eat doesn't satisfy our physiological needs alone (Cohen \& Farley, 2008), it is an important form of social communication (Marrone, 2001); (Parasecoli, 2011), it defines psychological conceptions (Meule \& Voegele, 2013); (Rozin, 1996) and reflects national culture (Montanari, 2006).

In Lebanon, taste and generosity are the general traits of local community and a specific aspect of local traditions. The influence of these traits on local food specialties has resulted in a rich assortment of savors and a wide variety of scrumptious dishes. For instance, Lebanese "Mezze" is a variety of 35 cold and hot appetizers, with various tastes, savor and presentation that reflect the specialty of different local communities, their tradition, creativity and refined taste. Going back to the root of this food diversity, we could relate it to three main factors: 1) the geography of Lebanon that, through its various climate zones (Mediterranean, valleys, mountains, swamps, etc.) and landscapes, has opened the way for food specialty by region or by territory, 2) the diversity of Lebanese ethnic groups (Arabs, Turks, Armenians, Africans, etc.) who enriched the local food culture with their traditional cuisine and cooking practices 3 ) the chronologies of national history. Generally speaking, the Lebanese cuisine features lightness, zest, richness and aroma combined in a large variety of mouthwatering dishes that associate the tradition and expertise of predecessors with the food specialty of different geographic areas. At the end, we can consider that national cuisine is the key for exploring our food culture, our local traditions, our ethnicity and history. Moreover, the way traditional food is prepared and served illustrates the behavior and the culture of different nations, it is a "system of communication, a body of images, a protocol of usages, situations and behavior" (Barthes, 1997).

The role that traditional cuisine plays in shaping national culture has been the subject of several studies in Semiotics: the study of communication and behavior related to culture (R. J. Andrew, Ian Vine), Gastrophy: the art or refined gluttony and eating habits (Fourier), Phagology: the study of habits related to eating or feeding, Social and Culture Anthropology: the study of norms and values of societies (Richard Harvey's, John Kersey's) and others. Talking about Gastrophy, it is the combination of five elements : agriculture, preservation, cooking, gastronomy and hygiene (Walker, 2002). The practice of Gastrophy depends on the eating habits and traditions developed historically by nations or persons, it reflects regional characteristics of food, eating traditions, cultural 
heritage and identity (Stano, 2016). However, the development of eating habits and tradition is not an individual effort, it is the result of the collective efforts of a group of actors who share formal and informal relationships inside and outside their territory. These relations correspond to networks that have positive influences on the socioeconomic development of the territory.

Having a look on Lebanese food eating habits, the Lebanese community follows a Mediterranean diet that is based on a balanced combination of proteins (dairy products and flesh), carbs (vegetables and beans) and Fats (olive oil). This diet has influenced the food choice and the methods of cooking for the Lebanese community and has become part of its culture. On the other hand, the Lebanese culture, that was influenced by the traditional cuisine, has had its impact on the behavior of the Lebanese community (rational cooking and balanced eating behaviors) as well as on the means of communication that have become part of national traditions. In general, food has an immense cultural and social meaning in Lebanon, it is the anchor of the family. For instance, the traditional Barbecue that gathers family members on holidays, the Ramadan breakfast that gathers family members every night, the sweets that assemble family members on happy and sad occasions etc. are just few examples about family-communication means that are centered around food. As for the aspect of Phagology in Lebanese cuisine, the Lebanese community is composed of eighteen confessions who differ with their religious beliefs and perceptions about food (food myths and stereotypes, religious beliefs) but share common social networks and norms of reciprocity and trust. This diversity of the Lebanese community has participated in developing a significant social capital that enriched the Lebanese cuisine with lavish menu varieties and tastes. Finally, beside the general consensus about the important role of traditional cuisine in shaping national culture, preserving local food culture and protecting national eating etiquette are of the same importance.

Referring to the findings of the survey conducted for the purpose of this paper, $40 \%$ of respondents claimed that they eat out daily, the majority of them, although favors international cuisines, the basic staple dishes for them remain traditional. Despite the fact that the Lebanese community is attached to its culture and traditions, particularly to its cuisine, Lebanese people love to explore new cultures and keen on creativity and innovation. This could explain why, based on the results of our study, the choice of families has been shifting towards international cuisines and modernized Lebanese cuisine over the last two decades (based on cross-tabulation analyses for the favorite restaurant type and concept, $43.75 \%$ of respondents who favor fast-food prefer international cuisines and $31.25 \%$ of these respondents favor the modernized Lebanese cuisine). In all cases, this rise is not expected to continue as, on the first hand, it is related to the middle and high-income category of Lebanese who, particularly, earn a higher disposable income than the previous generation but still represent a minority. On the other hand, what is considered new now, will become old in the future. Finally, we should not forget the rising of health consciousness in the Lebanese community, what promotes back again the traditional cuisine on behalf of the international and may foster, at a later stage, the home-made meals.

\section{The Impact of Globalization on Local Economies and Societies}

Globalization is considered as a powerfully real aspect of the new world system and it has many dimensions: economic, political, social, cultural, environmental, security and others (Gangopadhyay, 2017). Dreher (2006) defined globalization as a process that erodes national boundaries, integrates national economies, cultures, technologies and governance, and produces complex relations of mutual interdependence. For this author, globalization is the process of creating networks of connections among actors at intra- or multi-continental distances, mediated through a variety of flows including people, information and ideas, capital, and goods.

Globalization could be measured through several indices, the mostly known one is KOF. This globalization index is composed of three sub-indices: economic (weighting: 60 percent), social (weighting: 20 percent) and political (weighting: 20 percent). Economy sub-index is an indicator for cross border transaction ties in goods, services and wages, as well as capital controls. The social sub-index includes indicators for cultural proximity and personal contacts with other nations. Finally, Political sub-index is an indicator of the number of international agreements or memberships in international organizations. For instance, Lebanon has been considered as one of the emerging countries with a KOF globalization index of 66.52 (58 $8^{\text {th }}$ class) in 2017 (Gygli, Haelg, \& Sturm, 2018). This index was calculated based on an economic globalization sub-index of $73.3\left(50^{\text {th }}\right.$ class), a social globalization sub-index of $65.12\left(55^{\text {th }}\right.$ class $)$ and a political globalization sub-index of 59.67 (124 ${ }^{\text {th }}$ class).

Although the conception, among the general public about globalization is negative, there is a general consensus among economists that the benefits associated with globalization overweight the costs, especially in the long-run, 
in terms of GDP per capita ${ }^{1}$. Some of the benefits of globalization include: economic growth, Foreign Direct Investments (FDI), market efficiency, development of new technology due to increasing competition, economies of scale, peace, etc. As for the disadvantages of globalization, they include, but are not limited to: threats to local culture, structural unemployment, monopoly power of multinationals, unparalleled growth, increased inequalities, etc.

\subsection{Benefits of Globalization}

\section{A. Foreign Direct Investment}

FDI has been considered "the peak" of globalization process (Donciu, 2013), the globalization index released yearly, especially by A. T Kearney, has become a very important measure of globalization for most countries. The calculation of this index incorporates economic variables, one of which is FDI and Trade. According to the United Nations Conference on Trade and Development (UNCTAD), Lebanon was the top performer in attracting FDI in western Asia with FDI inflows accounting for 4.94 percent of GDP in 2016. In contrast, global FDI fell to USD 1.52 trillion in 2017, comparing to USD 1.81 trillion in 2016 (UNCTAD, 2018). This fall was probably due to the global decrease in the value of cross-border M\&As (IDAL, 2018). In fact, the trade deteriorations in Middle-East oil exporting economies due to the dramatic fall of crude-oil prices, accompanied with the military conflicts of GCC in Yemen, as well as the political conflicts with Qatar, not to forget the economic uncertainty in oil-importing countries, all have participated in dropping FDI outflows of GCC countries in Lebanon. On the other hand, the FDI inflows, registered in 2017, have revealed a clear interest by international organizations to establish branches in Lebanon, especially in non-tourism-related industries, such as the media sector. According to IDAL (2018), "one of the main trends characterizing these investments is a shift away from capital-intensive projects towards knowledge-intensive ones".

Being a capital-intensive sector, tourism has witnessed a drop in FDI in 2017. This can be noticed through the number of issued guarantees, for tourism projects, which dropped from 125 guarantees in 2016 to 117 guarantees in 2017 (BLOMINVEST, 2017). Consequently, the central bank has injected an additional $\$ 500$ million to the stimulus package for 2017 in order to boom the tourism sector and to attract further investments. The intervention of the central bank has had its effects on tourist arrivals who hit their highest level since 2011 with 1.85 million tourists and 8.23 million airport passengers, but, at the same time, FDI hasn't been improved due to the recurrent political shocks at the country and in the region.

\section{B. Economic Market Efficiency}

Efficient markets are those, when at equilibrium, have consumer's surplus equal to producer's surplus. In other terms, when markets are efficient, marginal benefits equal marginal costs, and economic efficiency occurs when marginal social benefit equals marginal social cost (Brueckner, 1982). Due to globalization, local actors will have the opportunity to outsource certain processes that improve their production or to import directly their raw materials and equipment at a discounted price. Consequently, production costs will decrease, profits will increase at a lower price and sales will increase until the consumer surplus equals the producer surplus. However, in a perfect competitive market, such as in Lebanon, international restaurants, equipped with new production technologies and years of experience, will be able to realize an economy of scale and will tolerate a decrease of their surplus for the benefits of consumers, at least in the short run, what will hurt local restaurants and affect their continuity into business. Furthermore, in the long run, with the decreasing number of local restaurants that serve traditional cuisine, local food culture will be badly affected.

\section{Development of a new technology}

As previously mentioned, the modern technology adopted by international restaurants, of the developed countries, helps improving the efficiency of processes and ameliorating the quality and the quantity of the output. These advantages have created an incentive for traditional restaurants, of the developing countries, to seek technological progress, to innovate and to diffuse new methods in an attempt to maximize profits through process amelioration and product innovation. Due to the continuous process of research and development for a modern technology, positive externalities (beneficial spillovers to a third party) will be generated and social benefits will improve. Generally speaking, globalization enables competitive industries, such as the hospitality industry, to expand in size but if the industry is fairly competitive, a Kaldor-Hicks gain is likely to eventuate (Tisdell, 2008). On the other flip, Schumpeter (1942) has a different point of view about the relationship between globalization and long-term

\footnotetext{
${ }^{1}$ Regression analyses are used to determine the correlation between sub-indices and per capita growth. In general, economic interdependence has a significantly positive impact on economic growth, and global networking in the areas of society and politics also leads to higher per capita growth.
} 
technical progress. According to Schumpeter's theory, that considers an inversely related function between; on the first hand; the rate of technological progress and innovation in an industry and; on the other hand; the degree of economic concentration, technological progress will be delayed in presence of globalization. In short terms, Schumpeter's theory considers no evident relationship between globalization and long-term technical progress.

\section{Economies of scale}

Due to globalization, large international organizations would be able to produce in different regions of the world and to enhance their specialization which, in turn, would permit an economy of scale. Although economies of scale are in favor of economic growth (Samimi \& Jenatabadi, 2014), this is not at no cost as international organizations will compete local ones domestically. On the other hand, globalization will help local actors to import cheaper raw materials and will allow access to advanced and efficient technologies, what will, in turn, enable a lower average cost of production and an economy of scale.

\section{E. Standard of Living}

Living standard is a result of globalization. By having taboo products affordable, the living standard of people increases. On the other hand, the increasing GDP per capita, due to globalization, will encourage households to increase their purchase of durable goods, to spend more money on restaurants and entertainment, and to ameliorate their life style.

\section{F. Foreign exchange reserves:}

Due to globalization, international financial flows increase and foreign exchange reserves increase as well.

\subsection{Threats of Globalization}

As previously mentioned, globalization is able to change the global economy, society and policy, it offers an opportunity to local actors to access global markets and to increase their efficiency. Despite its opportunities, globalization represents some threats as accessing new markets does not necessarily guarantee that the benefits of increased efficiency are shared by all equally (IMF, 2000). Among the various aspects of globalization (economic, financial, technological, sociopolitical processes, etc.), this paper focuses on three main threats: economic, social and cultural.

\section{A. Economic Globalization:}

According to Mikhailovna (2016, p. 21), economic globalization is "a combination of two processes: globalization of markets (capital, labor resources, goods and services), and globalization of organizational structures of economy, i.e., the establishment of global super-corporations". For this author, globalization leads to a new form of colonization as it brings the developing countries to the financial and economic slavery, and contributes to weakening national states and their sovereignty, in addition to threatening national security. This point of view was ascertained by Arrow (2018) who considers that globalization has some implications for the preservation of international security. On the other hand, trans-border trade and free trade are other threats of economic globalization, mainly for developing countries, due to their vulnerability in an incomplete market structure (Hart, 1975). Recently, the effects of globalization on labor market, particularly on the mobility of labor across borders, has been of a thorny debate among nations with the appearance of new immigration policies and trade regulations in the context of capital mobility (Baghdadi \& Banat, 2014). On the other flip, the invasion of international restaurants, supplied with modern technology and processes; professionalism and enormous financial backup, for local food market, is an explicit example of economic globalization.

\section{B. Social Globalization}

Researchers have different opinions about globalization and its effects on society. Some of them have determined an inverse relationship between globalization and poverty, while others have considered that globalization participates in widening the gap between rich and poor countries through the unbalanced economic growth. In all cases, it was noticed, since mid- $20^{\text {th }}$ century, that globalization has participated to economic growth of wealthy countries and worsened the poverty of poor countries which, in turn, had instant consequences on their populations in terms of education, health, life style, etc. In this context, the openness of local communities, in poor countries to international tourism has been the leverage for local economies and a relish for local communities but a disaster for local culture. In other terms, local communities in poor countries have benefited from the free access to information, that is provided by globalization, in order to serve the needs of the international tourism market, but failed to limit its negative impacts on the whole society. In Lebanon, as a matter of fact, sellers of artisanal products have generated enormous profits by importing ready-made traditional articles at a low cost (e.g Baalbek ruins souvenirs are made in China) instead of buying them from local 
producers. Consequently, many handicrafts and traditional specialties disappeared, what affected thereby the source of revenue of concerned societies and communities. Looking at it from Pareto efficiency model, "no one can be made better off without some being made worse off", globalization could then be considered as a leverage for local societies if the social benefits encountered from globalization are greater than its costs.

\section{Cultural Globalization}

Watson (2016) defines cultural globalization as a phenomenon by which the experience of everyday life, as influenced by the diffusion of commodities and ideas, reflects a standardization of cultural expressions around the world. Propelled by the efficiency or appeal of wireless communications, electronic commerce, popular culture, and international travel, globalization has been seen as a trend toward homogeneity that will eventually make human experience everywhere essentially the same. This appears, however, to be an overstatement of the phenomenon. Although homogenizing influences do indeed exist, they are far from creating anything akin to a single world culture.

Cultural globalization has been studied by several researchers in economics, management, sociology, political science, international relations and geography. According to Crane (2011), the two principal theories of cultural globalization are: imperialism ( in which a culture is imposed or dominates other cultures, beliefs, values, behavioral norms \& life style) and hybridization ( the merge between cultures result in a new version of culture). In general, the merge between two cultures requires an integration of foreign values into local culture. The degree of integration (cultural flow) depends on the characteristics of local culture and the level of attachment of local societies to their culture (locals) or their openness to cultural diversity (cosmopolitans) ${ }^{2}$. Significantly, conflicts between global and local cultures may rise, causing cultural clashes and even clashes of civilizations (civil, religious, political, etc.) ${ }^{3}$, it all depends on the "homogeneity" and the "heterogeneity" of global culture. In the same vein, Hannerz (1990) spoke about cultural homogenisation as a facet of global cultural development, illustrating with the example of McDonalds and Coca Cola who reflect a form of cultural globalization that represent the values of American culture. The influence that American culture and business processes have on other countries, such as in commerce; trade; industry; media; cuisine; life style; art; technology or politics, have been nominated "Americanisation" or "Americanization", a term that has first appeared in early $20^{\text {th }}$ century with the work of Stead, W.T. (1901) and Moffett, S.E. (1907). Although Americanisation seems to be a phenomenon of cultural globalization that attempts to export the American culture to the rest of the world, it did not find its way in Japan due to the strong normative and cognitive structure of Japanese social capital (Delanty, 2003), what spots the lights on the ability of nations to withstand outside corruption of their cultural beliefs from western influences.

\section{The Impact of Globalization on National Food Culture}

The impact of globalization on food culture, in terms of food preparation and consumption patterns, has gained a greater attention in the last two decades with the rise of health consciousness. In the same vain, Braudel (1983) has related food consumption patterns to the societal class structure, what raises the concern about the impact of health consciousness and Americanization on local food culture in presence of, on the first hand, a diminishing demand for traditional greasy food by the high-class society and, on the other hand, an increasing demand for affordable quick meals by the lower-class society which is the mostly affected by the Americanization.

Talking about cultural interaction between nations and Americanization, Bhugra (2004, p. 129) considers that "when people migrate from one nation or culture to another, they carry their knowledge and expressions of distress with them. On settling down in the new culture, their cultural identity is likely to change and that encourages a degree of belonging; migration can lead to loss of cultural norms, religious customs, and social support system". For instance, the Lebanese diaspora has participated, in turn, in integrating foreign food cultures into the Lebanese cuisine and vice versa (according to the Lebanese ministry of foreign affairs, the Lebanese diaspora exceeds 12 million worldwide, 8 million of them live in Brazil).

For years, the Lebanese cuisine has influenced, and was influenced by local, regional and even international food cultures. Possessing idiosyncratic ingredients; particular food preparation and preservation practices; specific methods of cooking and serving; distinguished customs and traditions; a complex combination of religious beliefs and unique climate conditions, each area of Lebanon has developed its own identity and its distinctive food culture. However, due to globalization, the exposure of local community to eastern and western cultures has increased, so has been the need to modernize the traditional cuisine. Consequently, new restaurant concepts were

\footnotetext{
${ }^{2}$ See (Strand, 2010)

${ }^{3}$ See (Huntington, 1996).
} 
developed and new styles of food consumption patterns have been embraced, what facilitated the partial diversification of traditional cuisine and enriched the local and national food cultures. On the other flip, the socioeconomic pressures on mid and low-class societies were in favor of the fast-food industry which, through globalization, has boomed and managed to alter the eating habits of Lebanese society, more specifically, with less focus on dining time and food quality.

In fact, due to economic reasons, the number of working households in Lebanon has been increasing, so was the search for an affordable quick meal, while the time allocated for preparing home food has been in a continuous decline. In the same vein, globalization has induced changes into business processes that became more demanding, with more emphasis on working schedules, what shortened the lunch break and increased the need for fast-food. In order to coop with the changing demand, food experts have been obliged to innovate and to modernize the traditional Lebanese cuisine by introducing international ingredients and unfamiliar cooking techniques that are unusual to the Lebanese food culture (e.g Quinoa in Tabouleh, Chocolate syrup in Kenafe, grilling Taouk instead of charbroiling, etc.), what threatens, in turn, the original identity of the Lebanese cuisine and risks to gradually detach it from its culture and traditions.

Despite its negative impacts on national food culture, globalization has some positive impacts that could be illustrated with:

- Globalization has helped spreading the Lebanese food culture, thanks to modern transportation and modern communication.

- Integration of local and global food culture skills and values.

- The acquisition of modern technology that facilitated the specialization of Lebanese cuisine (food processing, food preservation, etc.)

- Globalization has opened the opportunity for Lebanese food and beverage makers to export to global markets (roasted nuts, wine, sweets, canned food, etc.)

\section{Social Capital \& Networks: Tools for Food-Culture Preservation and Sustainability in Presence of Globalization}

Local development is the set of activities undertaken by local actors whose goals may be different. One of the most important resources in the process of local development is social capital, a term used among academic researchers, public authorities and international organizations, such as the world bank, to express "social networks and norms of trust and reciprocity that flourish through these networks" (Sander \& Lowney, 2006, p. 23). This new type of capital is understood as "an important resource of individuals and social groups impacting on economic growth, democratic practices, quality of governance and quality of life" (Murzyn-Kupisz \& Dzialek, 2013 , p. 36). The social capital of a community could be then considered as the composite of its culture, networks and the level of mutual trust between participants of these networks. There are different forms of social capital based on network conception: bonding, linking and bridging (Beaumont \& Dredge, 2009), (Dahal \& Adhikari, 2008). The relationships that build these forms of social capital are characterized by the existence of values and rules of conduct, such as confidence and good citizenship, between network members. In Lebanon, various food networks are characterized by their attachment to national products and ingredients all along the value chain. For instance, kitchen chefs still favor local ingredients and food items (sumac, pistachios, pines, red mullet fish, local wines, etc.) over imported ones, while Lebanese customers, in general, prefer (baladi $\left.{ }^{4}\right)$ products and ingredients over imported ones. This common concern for producers and customers, added to the good citizenship that characterizes them, has strengthened the relationship between members of different food\& beverage networks and enticed them to develop new formal and informal ways of communication and cooperation in order to ameliorate the quality and the competitiveness of national food and beverage products.

In brief, social capital represents the formal and informal relationships that exist between players inside and outside a territory. These relations correspond to networks that have positive influences on the socio-economic development of the territory. According to Pecqueur (1989, p. 54), local development dynamism refers to the "consequences of a favorable combination of individual projects which partially meet on common interests. These combinations form networks that are based on the cooperation of their partners and stand out other systems based on total independence or on the hierarchy". Pecqueur, for his part, distinguishes three types of networks: material flow networks, informal networks and networks of relationships of an institutional nature. A literature review on the various types of networks, has determined the following dimensions: flows, character

\footnotetext{
${ }^{4}$ Baladi means local in Arabic.
} 
(vertical, horizontal or mixed networks), length of the relationship, nature (formal or informal), network strength, etc. In the search for the most active network in local development, Gouttebel (2003, p. 104) considers "business networks in a dense SME economy".

As previously mentioned, due to globalization, the traditional Lebanese cuisine has witnessed tremendous conceptual changes with more focus on modernization and innovation. Food experts, culinary institutions, local municipalities and other private and public organizations (formal and informal) have played a tremendous role in developing the traditional Lebanese cuisine while keeping attachments to the roots and traditions. The ability of these networks in developing and modernizing the traditional Lebanese cuisine is due to their organizational conditions that stand behind the dynamics of innovation, thus called "innovation networks" (Krohn, 1995, p. 31). According to Ferguene (2011, p. 97): "the dynamics of innovation through network organization lead to a new type of network that is called: the innovation network". For its members, the innovation network is a way to reach new territories, to access and to share common resources.

\subsection{Innovation Network: The Solution to The Problem of Traditional-Cuisine Modernization and Food-Culture Preservation}

According to Maillat D. et al (1994) the innovation network is a coordinated set of heterogeneous and professional actors who collectively take part in the development, production and dissemination of processes of production of goods and services which give rise to a transaction market. In other words, the innovation network reflects a strategy of cooperation which, according to Gouttebel J.-Y. (2003, p. 119), "participates in an improvement in creativity and is a pooling of risk and costs specific to the innovation process".

From these definitions of innovation network, we can conclude its four dimensions:

- An economic dimension: it corresponds to a reduction in transaction costs related to the market in absence of a rigid hierarchy.

- A historical dimension: it is a mode of organization of transactions based on relationships of trust and knowledge, cooperation and reciprocity, that evolves over time.

- A normative dimension: the existence of rules of conduct and business procedures delimits the course of action of local actors and ensures product/service consistency.

- A cognitive dimension: this dimension means that the innovation network is a breeding place of knowledge and skills as well as a place of exchange of experiences.

What can be learned from the definition of Gouttebel is that local actors, who engage in a collective strategy, are willing to share the risks inherent in innovation to achieve a common goal. To do this, they need a genuine territorial policy which, according to Gouttebel J.-Y. (2003, p. 170), meets four conditions:

- Involve local players beyond the companies.

- Encourage the development of the specific territorial intangible capital (expertise, specialized technology, rules of trust, etc.).

- Search for and encourage synergies and, what specialists call, the learning effects between the actors. This is to develop the advantages of proximity and the collective ability to adapt to change.

- Ensure the technical environment - market relationships.

In the same framework, Boureille, B., \& Guesnier, B. (1994), consider two types of indistinguishable innovation networks:

- The network leader or hierarchical, in which the leader firm controls the entire process while the satellite institutions have no relationship between they.

- Partnership networks, which aim to develop an ongoing capacity for innovation. Then it's systematic innovation in which technology feedback on the other.

In general, different aspects of innovation networks have been studied based on: structure (Wasserman \& Faust, 1994); (Newman, 2003); (Fagerberg, Mowery, \& Nelson, 2006), links between actors (Granovetter, 1973); (Smith \& Ho, 2006); (Ahuja, 2000) and communication (Gloor, 2006); (Ahrweiler, Pyka, \& Gilbert, 2011). In all cases, the notion of "innovation networks" necessitates two components (Ahrweiler, 2010) : 1) structural (actors and their relationships) and 2) a social system of dedicated communications ${ }^{5}$.

\footnotetext{
${ }^{5}$ Refer to (Luhmann, 1987).
} 
Going back to the case of Lebanon, due to globalization, famous kitchen chefs, food experts and culinary schools have been forced to introduce international food items into national cuisine (ethnic and specialty items), new types of ingredients into traditional food composition (avocado, quinoa, fresh cream, sweet \& sour sauce, etc.) and new processes of food preparation and preservation (grilling instead of charbroiling or roasting, steaming instead of boiling, smoking instead of drying, etc.). In fact, the collective efforts of food industry players (including formal and informal institutions), who: 1) share the same values and concerns about innovating and promoting the food industry and 2) belong to formal and informal networks that seek to modernize and ameliorate the competitiveness of traditional cuisine, have generated innovative ideas and processes that participated in developing the traditional cuisine and enriching the local food culture while preserving its original identity.

The process of innovation is not new to Lebanese cuisine, with reference to history, the traditional Lebanese cuisine is a Levantine, several Lebanese specialties refer to eras of Romans $\left(8^{\text {th }}\right.$ century B.C) and Phoenicians (1500-300 B.C). In modern history, the Lebanese cuisine was influenced by the different foreign civilizations that held power, namely: the Ottoman Turks who ruled Lebanon between 1516 and 1918 and introduced a variety of foods that have become staples in the Lebanese $\operatorname{diet}^{6}$ such as cooking with lamb, and the French who ruled from 1918 to 1943 and introduced foods such as French bread, caramel custard, cakes, croissants, etc. (Choueiri, 2002).

The noteworthy innovations that characterized the Lebanese cuisine, in the last two decades, have been perceived with appreciation, especially by the new generation with more focus on internationalization, and hesitation from the part of the elder generation that is strongly attached to traditions and customs. In general, the Lebanese food culture has witnessed several innovations and ameliorations since its appearance and will continue to develop even more with the ever-changing demand and taste of new generations who are influenced by the Americanization. This innovation usually goes through two steps: the first is an evaluation of the national resources (traditional processes, techniques and ingredients) and those which can be mobilized in the area (innovative ideas, practical processes, healthier and tastier ingredients), the second is to develop the know-how and to improve the available resources for a better valorization. To achieve its objectives, the modernization of traditional Lebanese cuisine has to go through an innovative process that integrates all players into a collective action, the success of the process depends on the capacity of innovation networks to create innovative activities and to modernize the Lebanese cuisine while preserving its identity and maintaining the traditional food culture. According to Maillat \& Lecoq (1994, p. 79): "innovative activity opens, in turn, the horizon for new innovative activities; it is of the independent sequences of innovative processes".

\subsection{Networks as a Mean for Sustainable Territorial-Development Strategies}

According to Leloup, Moyart et Pecqueur (2005), the boundaries of the territory are more defined in reference to a political and administrative area or as a fragment of the national productive system, they define the place of: 1)intersection of networks (physical or human, formal or informal), 2)strategies and interdependencies between partners linked together, 3) the place of production, trading, sharing a common future. The system is built on several factors such as the proximity of these actors, the common dynamism that brings them together, the common trust that relates them, the set of rules; standards and principles accepted and implemented by all network members.

The importance of networks for local development is extended, not only, to facilitate the flow of information between actors of a territory, but also to encourage a collective action in planning and implementing development projects such as food-culture preservation. According to Gouttebel J.-Y. (2003, p. 111) : "networks create positive externalities that favor the flexibility of the production system and the economies of agglomeration". The flexibility is related to the small size companies or production units, the density of the relations between them, and their ability to quick adaptation to internal and external changes, whereas the economies of agglomeration are based on an intensification of the division of labor and productive specialization.

In terms of sustainability, the increasing concerns about the preservation of national culture, limitation of internationalization, and rationalization of the modernization process, have all induced a mandatory change in business processes and restaurant conception. The focus is now on gaining a competitive advantage by adopting business measures that preserve local food cultural and maintain a compromise between environmental, economic and social objectives. However, to achieve these sustainable development objectives, a collective

\footnotetext{
${ }^{6}$ Many traditional Lebanese items hold an ottoman nomination such as Tawouk "chicken”, Kebab "meat skewers", Baklawa "Turkish sweets", etc.
} 
strategy of food culture preservation should be adopted, by all players, within the guidelines of policy makers.

What facilitates the achievement of sustainable development objectives is the existence of common concerns, values and culture (social capital) among different players. Hence, this collective strategy of food culture preservation may find its application in the system of networks, where players enjoy the traditions of cooperation and mutual trust, and present different forms of non-market coordination between them. In a dynamic perspective, the efforts of different local actors (food experts, culinary institutions, etc.) lead to a territorial development process. Thus, being part of active networks (formal or informal), these actors become able to apply the collective strategy of food culture preservation, in collaboration with local authorities, in service of sustainability.

The role of networks and social relationships, as elements that shape the collective learning and territorial development, is developed by Angeon (2008) and Saxena (2003). Angeon argues that "territorial development results of the propensity of the actors to agree and to organize for collective action in response to one or more of the objectives they assign themselves to in common commitment" (Angeon, 2008, p. 239). As for Saxena (2003, p.1): "It is argued that sustainable tourism product is 'territorially embedded' in ongoing social networks and relationships". This leads to the need for cooperation between local actors and networks, to implement food-culture preservation strategies in service of sustainable development, based on synergies between territorial development strategies and business strategies.

Talking about business strategies, they have evolved since the 1970s, from a Taylorism model to a new model based on the concept of network. In the Fordism model, the business strategy was based on the search for ways to increase their market share, while the new space strategy is based on the interaction between the global and the local. In this context, the different food-service networks in Lebanon, whether formal or informal, should promote the preservation of local food-culture by proposing sustainable development strategies that focus on a rational modernization of traditional cuisine (based on the interaction between local and global food cultures).

\section{Practical Study}

This study aims to: 1) determine the factors that stand behind the preference of Lebanese community for a particular cuisine and 2) to evaluate the impact of four independent variables (Marital status, Dining-out frequency, Purchasing power and Food diet) on the choice of a restaurant type (Traditional, Modernized Lebanese, International and Fusion) and a restaurant concept (Fast food, Casual Dining, Fine dining and Family restaurant). Consequently, a regression analysis was conducted in order to evaluate the effects of the above-mentioned variables on the dependent variable, and an analysis of the correlation between each two variables (dependent and independent) has been provided.

Finally, based on the results of the correlation, a cross-tabulation analysis was done in order to determine the strength of the relationship between the specific variables that led us to the conclusion.

6.1 Regression Analysis: The Effect of Independent Variables on the Choice of Restaurant Type

Model Assumptions:

- a: coefficient of dining out frequency.

- $\quad$ : coefficient of marital status.

- c: coefficient of average annual income (purchasing power).

- $\mathrm{d}$ : coefficient of food diet and health consciousness.

- Y: The dependent variable that represent the choice of restaurant type (traditional, modernized Lebanese, international and fusion).

- X: Independent variable

- X1: Marital Status.

- X2: Dining-Out Frequency.

- X3: Average Annual Income.

- X4: Food diet 
Table 1 . Model summary for restaurant type

\begin{tabular}{|c|c|c|c|c|c|c|c|c|c|}
\hline \multicolumn{10}{|c|}{ Model Summary } \\
\hline \multirow[b]{2}{*}{ Model } & \multirow[b]{2}{*}{$\mathrm{R}$} & \multirow{2}{*}{$\begin{array}{c}\mathrm{R} \\
\text { Square }\end{array}$} & \multirow{2}{*}{$\begin{array}{l}\text { Adjusted R } \\
\text { Square }\end{array}$} & \multirow{2}{*}{$\begin{array}{l}\text { Std. Error of the } \\
\text { Estimate }\end{array}$} & \multicolumn{4}{|c|}{ Change Statistics } & \multirow[b]{2}{*}{ Durbin-Watson } \\
\hline & & & & & $\begin{array}{l}\text { R Square } \\
\text { Change }\end{array}$ & $\begin{array}{c}\text { F } \\
\text { Change }\end{array}$ & df1 df2 & $\begin{array}{l}\text { Sig. F } \\
\text { Change }\end{array}$ & \\
\hline 1 & $.846^{\mathrm{a}}$ & .717 & .671 & .95047 & .076 & 1.961 & $4 \quad 1985$ & .107 & 2.186 \\
\hline \multicolumn{10}{|c|}{$\begin{array}{l}\text { a. Predictors: (Constant), Do you follow a particular food diet?, What is your marital status?, What is your average annual } \\
\text { income?, How often do you dine out? }\end{array}$} \\
\hline \multicolumn{10}{|c|}{ b. Dependent Variable: What is your favorite restaurant type? } \\
\hline
\end{tabular}

Table 2. Coefficients for restaurant type

\begin{tabular}{|c|c|c|c|c|c|c|c|}
\hline \multicolumn{8}{|c|}{ Coefficients $^{\mathrm{a}}$} \\
\hline & & \multicolumn{2}{|c|}{ Unstandardized Coefficients } & \multicolumn{2}{|c|}{ Standardized Coefficients } & \multirow[b]{2}{*}{$\mathrm{t}$} & \multirow[b]{2}{*}{ Sig. } \\
\hline \multicolumn{2}{|c|}{ Model } & B & Std. Error & Beta & & & \\
\hline & (Constant) & 26.667 & 3.278 & & & 8.135 & .000 \\
\hline & Marital Status & -.088 & .018 & & -.733 & -4.858 & .123 \\
\hline & Dining-out Frequency & .138 & .087 & & .174 & 1.595 & .000 \\
\hline & Average Annual Income & .076 & .019 & & .438 & 3.948 & .001 \\
\hline & Food Diet & .544 & .885 & & .097 & .615 & .045 \\
\hline
\end{tabular}

a. Dependent Variable: what is your favorite restaurant type?

$\underline{\text { Regression analyses of the relationship between dependent and independent variables: }}$

- Based on Durbin Watson test, there is no collinearity between the independent variables.

- Based on the Adjusted value of the Coefficient of Determination, there is a strong impact of the independent variables (Dining out frequency, Average annual income and Food diet) over the choice of restaurant type, taking into consideration that $\mathrm{H} 0$ is accepted for Marital status.

- There is a positive and a significant correlation between "dining out frequency" and "the choice of restaurant type". This result indicates that when people are obliged to dine out on a daily basis (due to time and budget constraints), they go for an international fast food concept that provides a quick meal at an affordable price.

- There is a negative relationship between "marital status" and "the choice of restaurant type". In addition, this negative relationship is not even significant based on the t-value.

- There is a positive correlation supported by a considerable significance between "the average annual income" and "the choice of restaurant type" which means that: 1) dining out is not considered as an inferior good (positive income elasticity of demand) and 2) that the choice of restaurant type in Lebanon depends on the purchasing power of customers. Hence, the need to modernize the Lebanese cuisine in order to make it more competitive and more convenient for all socioeconomic categories.

- The relationship between "food diet, health consciousness" and "the choice of restaurant type" is positive. This means that the demand for a particular restaurant type depends on whether its food is healthy. On the other hand, the demand for a modernized Lebanese cuisine is significantly high, what explains the attachment of the Lebanese community to their cuisine due to its healthy food, with ascending desires to innovate it.

6.2 Cross-tabulation Analyses: The Relationship between the Choice of Restaurant Type and the Factors Determining It

The study has considered four factors that are in direct relation with the choice of restaurant type: food variety, food quality and taste, the new experience and portion size. The price was not considered as an influencing factor due to the fact that people are able to choose any restaurant type with the same budget. 
Table 3. Cross tabulation analyses for the factors determining the choice of a restaurant type

\begin{tabular}{|c|c|c|c|c|c|c|c|}
\hline \multicolumn{8}{|l|}{ Count } \\
\hline & & & \multicolumn{4}{|c|}{ Why do you prefer this restaurant type? } & \multirow[t]{2}{*}{ Total } \\
\hline & & & $\begin{array}{l}\text { Because of } \\
\text { food variety }\end{array}$ & $\begin{array}{l}\text { Because of food } \\
\text { quality and taste }\end{array}$ & $\begin{array}{c}\text { like to experience } \\
\text { new food creativities }\end{array}$ & $\begin{array}{c}\text { It serves a } \\
\text { large portion } \\
\text { size }\end{array}$ & \\
\hline \multirow{6}{*}{\multicolumn{2}{|c|}{$\begin{array}{l}\text { What } \\
\text { favorite } \\
\text { type? }\end{array}$}} & Traditional & 100 & 40 & 80 & 100 & 320 \\
\hline & & Lebanese & & & & & \\
\hline & & Modernized & 140 & 200 & 180 & 90 & 610 \\
\hline & & Lebanese & & & & & \\
\hline & & International & 160 & 140 & 380 & 40 & 720 \\
\hline & & Fusion & 60 & 80 & 190 & 10 & 340 \\
\hline Total & & & 460 & 460 & 830 & 240 & 1990 \\
\hline
\end{tabular}

\section{The Cross-Tabulation Analyses:}

- There is a strong link between the need to experience new food creativities and the choice of international cuisine and modernized Lebanese cuisine.

- There is a strong relationship between, on the first hand, food quality\& taste and, on the other hand, the choice of modernized Lebanese cuisine.

- There is a strong relationship between the choice of traditional cuisine portion size and food variety.

In conclusion, the increasing demand for international cuisine and modernized Lebanese cuisine is mainly due to their ability to provide a new dining experience (food creativity) in addition to food variety, quality and taste. Hence, the focus of several food networks should be directed towards innovating and modernizing the Lebanese cuisine while maintaining its traditional characteristics, namely: its food variety and generous portion size.

\subsection{Regression Analysis: The Effect of Independent Variables on the Choice of Restaurant Concept}

Model Assumptions:

- a: coefficient of dining out frequency.

- b: coefficient of marital status.

- c: coefficient of average annual income (purchasing power).

- $\mathrm{d}$ : coefficient of food diet and health consciousness.

- Y: The dependent variable that represent the choice of restaurant concept (Fast food, Casual Dining, Fine dining and Family restaurant).

- X: Independent Variable.

○ X1: Marital Status.

X X2: Dining-out Frequency.

○ X3: Average Annual Income.

○ X: Food Diet. 
Table 4. Model summary for restaurant concept

\begin{tabular}{|c|c|c|c|c|c|c|c|c|c|}
\hline \multicolumn{10}{|c|}{ Model Summary } \\
\hline \multirow[t]{3}{*}{ Model } & \multirow[t]{3}{*}{$\mathrm{R}$} & \multirow{3}{*}{$\begin{array}{c}\mathrm{R} \\
\text { Square }\end{array}$} & \multirow{3}{*}{$\begin{array}{l}\text { Adjusted R } \\
\text { Square }\end{array}$} & \multirow{3}{*}{$\begin{array}{l}\text { Std. Error of the } \\
\text { Estimate }\end{array}$} & \multicolumn{4}{|c|}{ Change Statistics } & \multirow[t]{3}{*}{ Durbin-Watson } \\
\hline & & & & & R Square & $\mathrm{F}$ & df1 df2 & Sig. F & \\
\hline & & & & & Change & Change & & Change & \\
\hline 1 & $.917^{\mathrm{a}}$ & .841 & 0.829 & .27076 & .030 & .739 & 41985 & .568 & 2.462 \\
\hline \multicolumn{10}{|c|}{$\begin{array}{l}\text { a. Predictors: (Constant), Do you follow a particular food diet?, What is your marital status?, What is your average annual } \\
\text { income?, How often do you dine out? }\end{array}$} \\
\hline \multicolumn{10}{|c|}{ b. Dependent Variable: What is your favorite restaurant concept? } \\
\hline
\end{tabular}

Table 5. Coefficients for restaurant concept

\begin{tabular}{|c|c|c|c|c|c|}
\hline \multicolumn{6}{|c|}{ Coefficients $^{a}$} \\
\hline \multirow[b]{2}{*}{ Model } & \multicolumn{2}{|c|}{ Unstandardized Coefficients } & \multirow{2}{*}{$\begin{array}{c}\text { Standardized Coefficients } \\
\text { Beta } \\
\end{array}$} & \multirow[b]{2}{*}{$\mathrm{t}$} & \multirow[b]{2}{*}{ Sig. } \\
\hline & B & Std. Error & & & \\
\hline 1 (Constant) & 2.083 & 0.295 & & 7.068 & .000 \\
\hline Marital Status & -.049 & .059 & -.036 & -.828 & .041 \\
\hline Dining-out Frequency & .046 & .019 & .139 & 2.386 & .019 \\
\hline Average Annual Income & .181 & .028 & .435 & 6.546 & .000 \\
\hline Food Diet & .046 & .026 & .116 & 1.777 & .047 \\
\hline
\end{tabular}

Analyses of the relationship between the choice of restaurant concept and independent variables:

- Based on Durbin Watson test, there is no collinearity between the independent variables.

- Based on the Adjusted value of the Coefficient of Determination, there is a strong impact of the independent variables (Dining out frequency, Average annual income and Food diet) over the choice of restaurant concept.

- It is obvious that the choice of restaurant concept is inversely related to marital status of respondents. In other terms, the size of the family is inversely related to the level of complexity of restaurant concept selected. For instance, families would prefer a traditional cuisine that offers familiar food whereas, newly married couples, for examples, wouldn't mind to try a new restaurant concept as part of their new life experience.

- There is a positive correlation between dining out frequency and the choice of a particular restaurant concept. Based on the previously determined relationship between restaurant type and dining out frequency, we can conclude that people who are obliged to dine out frequently prefer international fast food cuisine, in the first place, and modernized Lebanese cuisine in the second place.

- There is a significant positive correlation between average annual income and the choice of restaurant concept. Being positively correlated means that the choice of a particular restaurant concept is not inferior and, whether the income increases, the desire for a more sophisticated cuisine increases as well (what explains the shift towards fusion concepts).

- The relationship between food diet and restaurant concept is also positive as people on diet are very selective in their choice of a cuisine that provides necessary daily nutrients.

6.4 Cross-tabulation Analyses: The Relationship between the Choice of Restaurant Concept and the Factors Determining It

The study has considered four factors that are in direct relation with the choice of restaurant concept: ambiance, price, portion size, service and menu choice 
Table 6. Cross tabulation analyses for the factors determining the choice of a restaurant concept

\begin{tabular}{|c|c|c|c|c|c|c|c|}
\hline \multicolumn{8}{|l|}{ Count } \\
\hline & & \multicolumn{5}{|c|}{ Why is this your favorite concept? } & \multirow[t]{2}{*}{ Total } \\
\hline & & Ambiance & Price & Portion size & Service & Menu choice & \\
\hline \multirow{4}{*}{ What is your favorite restaurant concept? } & Fast food & 20 & 650 & 80 & 120 & 60 & 930 \\
\hline & Casual dining & 60 & 40 & 160 & 200 & 80 & 540 \\
\hline & Fine dining & 100 & 20 & 0 & 80 & 0 & 200 \\
\hline & Family restaurant & 60 & 50 & 100 & 60 & 50 & 320 \\
\hline Total & & 240 & 760 & 340 & 460 & 190 & 1990 \\
\hline
\end{tabular}

The Cross-tabulation analyses revealed:

- A strong correlation exists between, on the first hand, the choice of fast food restaurants and, on the other hand, price convenience and service rapidity.

- A strong correlation exists between, on the first hand, the choice of casual dining concept and, on the other hand, portion size and service quality.

Conclusion:

The choice of a fast food concept is mainly due to price convenience and service rapidity, based on the cross-tabulation analyses about the choice of restaurant concept, the preferred cuisine will be an international fast food which has a convenient price, quick service and food creativity. On the other hand, there is another choice, of similar importance, for modernized Lebanese casual dining which provides a large portion size, a quick service, food taste and quality, in addition to food creativity.

Finally, we can conclude that traditional Lebanese cuisine, whether being a fast-food or a casual diner, should focus on price, service standards and food creativity in its modernization process while keeping an eye on food variety and portion size.

\section{General Conclusion}

The debate about the socio-cultural impact of globalization never ends. For some, globalization eradicates local culture and affects local values, whereas for others, globalization participates in revitalizing and stimulating the reconstruction of local and regional values. In all cases, no one ignores the impacts of globalization, whether positive or negative, on local food culture. For the last two decades, due to globalization, the preferences of the Lebanese community have been shifting gradually towards international cuisines. Several factors (economic and social) have facilitated the penetration of international cuisine concepts into the local market, what started to threaten our traditional food culture. However, due to the strong social capital that characterizes the Lebanese society and the effective communication and coordination that exist between networks and members of these networks (restaurateurs, food experts, culinary schools and institutions), the threats of globalization to national food culture have turned into advantages. What facilitated this alteration is the existence of several specialized innovation networks whose focus is on modernizing the traditional cuisine in order to accompany the international tendencies and the changing demand. Consequently, innovative ideas have been generated and new processes have been invented, what participated in developing the traditional cuisine and enriching the local food culture while preserving its original identity.

Finally, the need for traditional cuisine and national food culture preservation has generated the need for a new form of inter-firm relations that seek synergies between local/national culture-development strategies, business strategies and sustainability. Hence, one of the important questions that arises, at the end of this research, is about the effective mode of regulation of inter-firm relations, in other terms: local governance.

\section{References}

Ahrweiler, P. (2010). Innovation in complex social systems. London: Routledge. https://doi.org/10.4324/9780203855324

Ahrweiler, P., Pyka, A., \& Gilbert, N. (2011). A New Model For University-Industry Linksin Knowledge-Based Economics. Journal of Product Innovation Management, 28, 218-235. https://doi.org/10.1111/j.1540-5885.2010.00793.x 
Ahuja, G. (2000). Collaboration Networks, Structural Holes, and Innovation. Administrative Science Quarterly, 45, 425-55. https://doi.org/10.2307/2667105

Angeon, V. (2008). L'explicitation Du Role Des Relations Sociales Dans Les Mécanismes De Développement Territorial. Revue D'Economie Régionale \& Urbaine, 2, 237-50. https://doi.org/10.3917/reru.082.0237

Arrow, K. (2018). Globalisation and Its Implications for International Security. In P. Gangopadhyay, \& M. Chatterji (Eds.), Economics of Globalisation (pp. 11-13). London \& New York: Routledge.

Baghdadi, I., \& Banat, R. (2014). The Impact of Syrian Immigration Shock On Wages In The Lebanese Fast-Food Labor Market. European Scientific Journal, 10(34), 105-116.

Barthes, R. (1997). Towards a psychosociology of contemporary food consumption. In C. Couninhan, \& P. Esteric (Eds.), Food and Culture (pp. 10-27). New York \& London: Routledge.

Beaumont, N., \& Dredge, D. (2009). Local Tourism Governance: A comparison of three network approaches. Journal of Sustainable Tourism, 18(1), 7-28. https://doi.org/10.1080/09669580903215139

Belasco, W. (2002). Food matters: perspectives on an emerging field. In W. Belasco, \& P. Scranton (Eds.), Food Nations: selling taste in consumer societies. New York: Routledge.

Bérard, L., \& Marchenay, P. (2004). Les Produits de Terroir: Entre Cultures et Règlments. Paris: CNRS. https://doi.org/10.4000/books.editionscnrs.9368

Bhurga, D. (2004). Migration, distress and cultural identity. $B r$ Med Bull, 69, 129-41. https://doi.org/10.1093/bmb/ldh007

BLOMINVEST. (2017). Lebanese Tourism Sector: 2017 in Review. Beirut: BLOMINVEST Bank.

Boureille, B., \& Guesnier, B. (1994). Dynamique Des Activités et Evolution Des Territoires: en hommage au professeur Pierre Mifsud. Sait-Etienne: Université de Saint-Etienne.

Braudel, F. (1983). La civilisation, l'histoire et l'aliment. Paris: Etoile Promotion.

Brueckner, J. (1982). A Test for Allocative Efficiency in the Local Public Sector. Journal of Public Economics, 19, 311-331. https://doi.org/10.1016/0047-2727(82)90059-7

Choueiri, R. (2002). The Culinary Heritage. Beirut: Ramzi Choueiri.

Cohen, D., \& Farley, T. (2008). Eating as an automatic behavior. Prev. Chronic Dis., 5, 1-7.

Crane, D. (2011). Cultural Globalization: 2001-10. 1-16.

Dahal, G., \& Adhikari, K. (2008). Bridging, linking and bonding social capital in collective action: the case of Kalahan Forest Reserve in the Philippines. CARPI Working Paper, 79.

Delanty, G. (2003). Consumption, modernity, and Japanese Culture Identity: The Limits of Americanization? In N. Sznaider, \& R. Winter (Eds.), Global America? The Cultural Consequences of Globalization (pp. 114-133). Liverpool: Liverpool University Press.

Donciu, E. (2013). Globalization and Foreign Direct Investments. CES Working Papers, 5(2), 177-186.

Douglas, M. (1971). Deciphering a Meal. In C. Greetz (Ed.), Myth, Symbol and Culture (pp. 61-82). New York: Norton.

Dreher, A. (2006). Does Globalization Affect Growth? Evidence from a new index of globalization. Applied Economics, 38(10), 1091-1110. https://doi.org/10.1080/00036840500392078

Fagerberg, J., Mowery, D., \& Nelson, R. (2006). The Oxford Handbook of Innovation. Oxford: Oxford University Press. https://doi.org/10.1093/oxfordhb/9780199286805.001.0001

Fallon, R., \& Pliner. (1984). The child's conception of food. The development of food rejections, with special reference to disgust and contamination sensitivity. Child development, 55, 566-575. https://doi.org/10.2307/1129968

Ferguene, A. (2011). Croissance économique et développement: Nouvelles approches. France: ADER.

Fischler, C. (1980). Food habits, social change and nature/culture dilemma. Social Science Information, 19(6), 937-953. https://doi.org/10.1177/053901848001900603

Gangopadhyay, P. (2017). Economics of Globalization. London: Routledge.

Gloor, P. (2006). Swarm Creativity: Competitive Advantage Through Collaborative Innovation Networks. Oxford University Press. https://doi.org/10.1093/acprof:oso/9780195304121.001.0001 
Gouttebel, J. (2003). Stratégies de Developpement Territorial. Paris: Economica.

Granovetter, M. (1973). The Strength of Weak Ties. American Journal of Sociology, 78, 1360-80. https://doi.org/10.1086/225469

Gygli, S., Haelg, F., \& Sturm, J. (2018). The KOF Globalisation Index Revised. Zurich: KOF Swiss Economic Institute.

Hannerz, U. (1990). Cosmopolitants and Locals in World Culture. Culture and Society, 7, 237-51. https://doi.org/10.1177/026327690007002014

Hart, O. (1975). On the Optimality of Equilibrium When the Market Structure is Incomplete. Journal of Economic Theory, 11, 418-43. https://doi.org/10.1016/0022-0531(75)90028-9

Huntington, S. (1996). The Clash of Civilizations and the Remaking of World Order. New York: Simon and Schuster.

IDAL. (2018, 6 18). Lebanon at a Glance. Retrieved from http://investinlebanon.gov.lb/en/lebanon_at_a_glance/foreign_direct_investments/

IMF. (2000, 4 12). Globalization: threat or opportunity. Retrieved from https://www.imf.org/external/np/exr/ib/2000/

Krohn, W. (1995). Die Innovationschancen partizipatorischer Technikgestaltung und diskursiver Konfliktregelung. IWT, Bielefeld.

Leloup, F., Moyart, L., \& Pecqueur, B. (2005). La Gouvernance Territoriale Comme Nouveau Mode de Coordination Territoriale? Géographie Economie Société, 7, 321-332. https://doi.org/10.3166/ges.7.321-331

Luhmann, N. (1987). Soziale Systeme. Grundriss einer allgemeinen Theorie. Frankfurt: Suhrkamp.

Maillat, D., \& Lecoq, B. (1994). Innovation Networks and Technology Dynamics: Tentative of Typology. In B. Johansson, \& L. Westin (Eds.), Patterns of a network economy. Berlin. https://doi.org/10.1007/978-3-642-78898-7_3

Maillat, D., Cervoisier, O., \& Lecoq, B. (1994). Innovation Networks and Territorial Dynamics: A Tentative Typology. In B. Johansson, C. Karlsson, \& L. Westin (Eds.), Patterns of a Network Economy (pp. 33-52). Berlin: Springer-Verlag Berlin Heidelberg. https://doi.org/10.1007/978-3-642-78898-7_3

Marrone, G. (2001). Corpi Sociali. Processi communicativi e semiotica del testo. Turin: Einaudi.

Meule, A., \& Voegele, C. (2013, April). The Psychology of Eating. Frontiers in Psychology, 4(215). https://doi.org/10.3389/fpsyg.2013.00215

Mikhailovna, O. et al. (2016). Economic Globalization: Challenges and Threats of the Russian National Security. International Journal of Economics and Financial Issues, 6(55), 20-25.

Moffett, S. (1907). The Americanization of Canada. USA: Colombia University.

Montanari, M. (2006). Food Is Culture: Arts and Traditions of the Table. New York: Colombia University Press.

MOT. (2018, May 2). Restaurants opened between 2000 \& 2017. Beirut, Lebanon: Ministry of Tourism.

Murzyn-Kupisz, M., \& Dzialek, J. (2013). Cultural heritage in building and enhancing social capital. Journal of cultural heritage, management and sustainable development, 3(1), 35-54. https://doi.org/10.1108/20441261311317392

Newman, M. (2003). The Structure and Funcion of Complex Networks. SIAM Review, 45, 167-256. https://doi.org/10.1137/S003614450342480

Parasecoli, H. (2011). Savoring semiotics: Food in intercultural communication. Social Semiotics, 21(5), 645-663. https://doi.org/10.1080/10350330.2011.578803

Pecqueur, B. (1989). Le développement local. Paris: Syros Alternatives.

Richards, A. (1939). Land, Labour, and Diet in Northern Rhodesia: an economic study of the Bemba tribe. Oxford: Oxford University Press.

Rozin, P. (1996). Towards a Psychology of Food and Eating: From Motivation to Module to Model to Maker, Morality, Meaning, and Metaphor. Current Directions in Psychological Science, 5(1), 18-24. https://doi.org/10.1111/1467-8721.ep10772690

Samimi, P., \& Jenatabadi, H. (2014, 4 10). Globalization and Economic Growth: Empirical Evidence on the Role 
of Complementarities. PLoS one, 9(4). https://doi.org/10.1371/journal.pone.0087824

Sander, T., \& Lowney, K. (2006). Social Capital Building Toolkit Verion 1.2. Civic Engagement in America, Saguaro Seminar. USA: J.Kennedy School of Government, Harvard University.

Saxena, G. (2003). Relationship, Networks And The Learning Regions: Case Evidence From The Peak District National Park. Tourism Management, 1-13.

Schumpeter, J. (1942). Capitalism,Socialismand Democracy (2nd ed.). New York: Harper Brothers.

Sims, R. (2009). Food, Place and authenticity: local food and the sustainable tourism experience. Journal of Sustainable Tourism, 17(3), 321-336. https://doi.org/10.1080/09669580802359293

Smith, H., \& Ho, K. (2006). Measuring the Performance of Oxford University, Oxford Brookes University and the Government Laboratories' Spin-Off Companies. Research Policy, 35, 1554-68. https://doi.org/10.1016/j.respol.2006.09.022

Stano, S. (2016). Semiotic of Food. Semiotica, 211, 19-26.

Stead, W. (1901). The Americanization of the World. Horace Markley.

Strand, T. (2010). Introduction: Cosmopolitanism in the making. Studies in Philosophical Education, 103-109. https://doi.org/10.1007/s11217-009-9168-9

Strauss, C. (1968). L'origine des manières de table. Paris: Plon.

Tisdell, C. (2008). Economic Theory, Applications and Issues. Queensland: Edward Elgar.

UNCTAD. (2018). World Investment Report. New York and Geneva: United Nations.

Walker, H. (2002). The meal. London: Prospect Books.

Wasserman, S., \& Faust, K. (1994). Social Network Analysis: Methods and Applications. Cambridge: Cambridge University Press. https://doi.org/10.1017/CBO9780511815478

Watson, J. (2016). Cultural Globalization. Retrieved from $\mathrm{http}: / / \mathrm{www} \cdot$ britannica.com/science/cultural-globalization

\section{Copyrights}

Copyright for this article is retained by the author(s), with first publication rights granted to the journal.

This is an open-access article distributed under the terms and conditions of the Creative Commons Attribution license (http://creativecommons.org/licenses/by/4.0/). 